\title{
Bulleidia extructa gen. nov., sp. nov., isolated from the oral cavity
}

\author{
Julia Downes, ${ }^{1}$ Bente Olsvik, $\dagger^{2}$ Sarah J. Hiom, ${ }^{1}$ David A. Spratt, ${ }^{1}$ \\ Sarah L. Cheeseman, ${ }^{1}$ Ingar Olsen, ${ }^{2}$ Andrew J. Weightman ${ }^{3}$ \\ and William G. Wade ${ }^{1}$
}

Author for correspondence: William G. Wade. Tel: +44 207955 2849. Fax: +44 2079552847. e-mail:william.wade@kcl.ac.uk

\footnotetext{
1 Oral Microbiology Unit, Division of Oral Medicine, Pathology, Microbiology and Immunology, Guy's, King's and St Thomas' Dental Institute, King's College London, Guy's Hospital, London SE1 9RT, UK

2 Institutt for oral biologi, University of Oslo, N-0316 Oslo, Norway

3 Cardiff School of Biosciences, Cardiff University, PO Box 915, Cardiff CF1 3TL, UK
}

\begin{abstract}
Five strains of anaerobic non-sporing Gram-positive bacilli isolated from advanced periodontitis (four strains) and a dentoalveolar abscess (one strain) that did not correspond to existing species were subjected to phenotypic and genetic characterization. Following 165 rDNA sequence analysis, they were found to constitute a novel branch of the low G+C Gram-positive division of the phylogenetic tree related to Erysipelothrix rhusiopathiae and Holdemania filiformis. A new genus Bulleidia, and the species Bulleidia extructa, are proposed. Growth of $B$. extructa in broth media was poor but was enhanced by the addition of fructose, glucose or maltose together with Tween 80 . Glucose and maltose were fermented and arginine was hydrolysed. Acetate, lactate and trace amounts of succinate were the end products of glucose fermentation. The G+C content of the DNA of the type strain is $38 \mathrm{~mol} \%$. The type strain of Bulleidia extructa is DSM $13220^{\top}$.
\end{abstract}

Keywords: Bulleidia, Eubacterium, taxonomy, phylogeny

\section{INTRODUCTION}

Anaerobic non-sporing Gram-positive bacilli currently assigned to the genus Eubacterium are an extremely diverse group of organisms (Moore \& Holdeman Moore, 1986). A number of new species have recently been proposed (Cheeseman et al., 1996; Poco et al., 1996a, b; Uematsu et al., 1993) and it is estimated that there are at least 25 un-named taxa (Wade, 1997). Phylogenetic analysis of 16S rRNA gene sequence data has placed most of these new species in either the Actinobacteria or the low $\mathrm{G}+\mathrm{C}$ Gram-positive division of the phylogenetic tree (Cheeseman et al., 1996; Wade et al., 1999). In this study, a group of isolates from oral infections, which could not be identified as belonging to an existing species, were studied.

\section{METHODS}

Bacterial strains. The strains included in the study had been provisionally identified as Eubacterium spp. (Wade et al.,

† Sadly, Bente Olsvik passed away in December 1998.

Abbreviation: PRAS, pre-reduced aerobically sterilized.

The GenBank accession number for the 16S rDNA sequence of Bulleidia extructa is AF220064.
1990; Olsvik, 1995). Strains GF10, MK1, UM3 and W1219 were isolated from periodontal pockets and W2274 was isolated from a dentoalveolar abscess. Erysipelothrix rhusiopathiae NCTC $8163^{\mathrm{T}}$ ( = ATCC $19414^{\mathrm{T}}$ ) was obtained from the NCTC and Holdemania filiformis ATCC 51649 ${ }^{\mathrm{T}}$ from the ATCC.

Morphology. Strains were grown at $37^{\circ} \mathrm{C}$ on fastidious anaerobe agar (FAA, LabM) supplemented with 5\% horse blood under anaerobic conditions $\left(80 \% \mathrm{~N}_{2}, 10 \% \mathrm{H}_{2}, 10 \%\right.$ $\mathrm{CO}_{2}$ ). Colonial morphologies were determined using a plate microscope after incubation for $7 \mathrm{~d}$. Cellular morphology was recorded after Gram-staining of $3 \mathrm{~d}$ plate cultures. Hanging-drop preparations of $18 \mathrm{~h}$ cultures of peptone/ yeast extract/glucose (PYG) broth supplemented with $0.5 \%$ Tween 80 were examined by phase-contrast microscopy for cellular motility.

Ultrastructure. Transmission electron microscopy was used to examine the cell-wall ultrastructure. Cells were fixed in $2.5 \%$ glutaraldehyde in $0.1 \mathrm{M}$ Sorensen's buffer, then centrifuged and washed in the same buffer. The cells were post-fixed in $1 \%$ osmium tetroxide, dehydrated by a graded series of ethanol, treated with propylene oxide and embedded in Taab epoxy resin. Ultrathin sections were stained with uranyl acetate and lead citrate for transmission electron microscopy.

Biochemical and physiological tests. Fermentation tests were performed using pre-reduced, anaerobically sterilized 
(PRAS) sugars according to the methods of Holdeman et al. (1977) except that the PRAS media were prepared in an anaerobic workstation using pre-reduced distilled water. Other biochemical tests were performed as described by Holdeman et al. (1977) and Summanen et al. (1993). Sensitivity to bile was determined by comparing growth of strains on FAA with and without $2 \%$ oxgall after $5 \mathrm{~d}$ incubation. Spore formation was assessed by both direct microscopic examination and culture following killing of vegetative cells by either heating to $80^{\circ} \mathrm{C}$ for $10 \mathrm{~min}$ or treatment with $95 \%$ ethanol for $30 \mathrm{~min}$. Temperature optima were determined by incubation of $\mathrm{PYG}+0.5 \%$ Tween 80 broth cultures at 30,37 and $42{ }^{\circ} \mathrm{C}$.

Metabolic-end-product analysis. Bacterial strains were grown in PYG broth supplemented with $0.5 \%$ Tween 80 and shortchain volatile and non-volatile fatty acids extracted by standard methods (Holdeman et al., 1977). Analysis was performed by GC with a capillary column coated with CPWax 58 (free fatty acid) solid phase.

Protein profiles. Protein profiles of whole-cell proteins were generated by SDS-PAGE using $10-15 \%$ gradient gels and the PhastSystem (Pharmacia) as described previously (Slayne et al., 1990) except that the cells were pre-treated with lysozyme $\left(50 \mu \mathrm{g} \mathrm{ml}^{-1}\right)$ for $3 \mathrm{~h}$ at $37^{\circ} \mathrm{C}$ and vortexed for 6 min with $1 / 10$ vol. $100 \mu \mathrm{m}$ diameter glass beads before boiling.

Enzyme profiles. Enzyme profiles were generated with the Rapid ID32A anaerobe identification kit (bioMérieux) according to the manufacturer's instructions. Bacteria were harvested from blood agar plates [Blood Agar Base No. 2 (LabM) supplemented with $5 \%$ horse blood] incubated anaerobically at $37^{\circ} \mathrm{C}$ for $72 \mathrm{~h}$.

16S rRNA gene PCR and sequencing. DNA was isolated from the bacteria by standard methods. The 16S rRNA gene was amplified by PCR using primers $27 \mathrm{~F}$ and $1525 \mathrm{R}$ (Lane, 1991). PCR amplification was performed with an Uno II Thermocycler (Biometra) using PCR buffer (Bioline) containing $1.5 \mathrm{mM} \mathrm{MgCl}, 200 \mu \mathrm{M}$ dNTPs, $1 \mathrm{mM}$ of each oligonucleotide primer, 1 U Taq DNA polymerase (Bioline) and template DNA (100 ng) in a total volume of $100 \mu \mathrm{l}$. Thirty amplification cycles were performed with denaturing at $94{ }^{\circ} \mathrm{C}$ for $1 \mathrm{~min}$, annealing at $54{ }^{\circ} \mathrm{C}$ for $1 \mathrm{~min}$ and elongation at $72{ }^{\circ} \mathrm{C}$ for $2 \mathrm{~min}$. PCR products were sequenced directly using a dye terminator cycle sequencing kit with AmpliTaq FS (Perkin Elmer) and $60 \mathrm{ng}$ template DNA, according to the manufacturer's instructions. Sequencing was performed using an automated sequencer (ABI 377; Perkin Elmer) with primers 27F, 342R, 357F, 519R, 907R, 926F, 1100R, 1114F, 1392R and 1525R (Lane, 1991).

Sequence analysis. Sequences were connected using DNASIS (Hitachi) and then submitted to the Ribosomal Database Project via the World Wide Web for provisional identification using the Similarity_Rank program. From the phylogenetic position indicated by Similarity_Rank, related sequences were selected and aligned by means of CLUSTAL W (Thompson et al., 1994). Further analysis was performed using the PHYLIP suite of programs (Felsenstein, 1993). Specifically, DNADIST was used to compare sequences by the Jukes-Cantor algorithm and NEIGHBOR was used for neighbour-joining cluster analysis.

Estimation of $\mathbf{m o l} \% \mathbf{G}+\mathbf{C}$ content of DNA. This was done by an HPLC method as described previously (Wade et al., 1999).

\section{RESULTS AND DISCUSSION}

Five strains of Gram-positive bacilli were studied. They were found to be obligately anaerobic, nonmotile, non-spore-forming short bacilli $(0.5 \times 0.8-$ $2 \mu \mathrm{m})$. Colonies on FAA were $0.8 \mathrm{~mm}$ in diameter, circular, entire, low convex and opaque after $7 \mathrm{~d}$ incubation. Growth in peptone/yeast extract broth was poor but was enhanced by the addition of $0.5 \%$ Tween 80 together with $1 \%$ glucose, maltose or fructose. Glucose and maltose were fermented, with acetate, lactate and trace amounts of succinate produced as the end products of metabolism. Cells grew in $\mathrm{PYG}+0.5 \%$ Tween 80 at 30 and $37{ }^{\circ} \mathrm{C}$ but not $42{ }^{\circ} \mathrm{C}$.

Transmission electron microscopic examination revealed a typical Gram-positive cell wall composed of a single layer of peptidoglycan approximately $55 \mathrm{~nm}$ thick surrounding the cytoplasmic membrane (Fig. 1).

All strains hydrolysed arginine. Catalase, indole and $\mathrm{H}_{2} \mathrm{~S}$ were not produced and nitrate was not reduced. Aesculin and urea were not hydrolysed and gelatin was not liquefied. All strains were positive for arginine dihydrolase, arginine arylamidase and leucine arylamidase in the Rapid ID 32A panel. The $\mathrm{G}+\mathrm{C}$ content of the DNA of strain $\mathrm{W} 1219^{\mathrm{T}}$ was $38 \mathrm{~mol} \%$.

16S rRNA gene PCR products obtained from strain $\mathrm{W} 1219^{\mathrm{T}}$ with primers $27 \mathrm{~F}$ and $1525 \mathrm{R}$ were fully sequenced. Approximately 550 bases of 16S rDNA were sequenced for strains GF10, MK1 and UM3 between bases 357 and 907 (Escherichia coli numbering). This stretch of sequence includes the variable regions V3-5 (Neefs et al., 1993). Over 545 aligned bases, each strain had $>99 \%$ sequence similarity with each other strain. Phylogenetic analysis of the sequence data assigned $\mathrm{W} 1219^{\mathrm{T}}$ to the clostridial subphylum within the low $\mathrm{G}+\mathrm{C}$ Gram-positive bac-

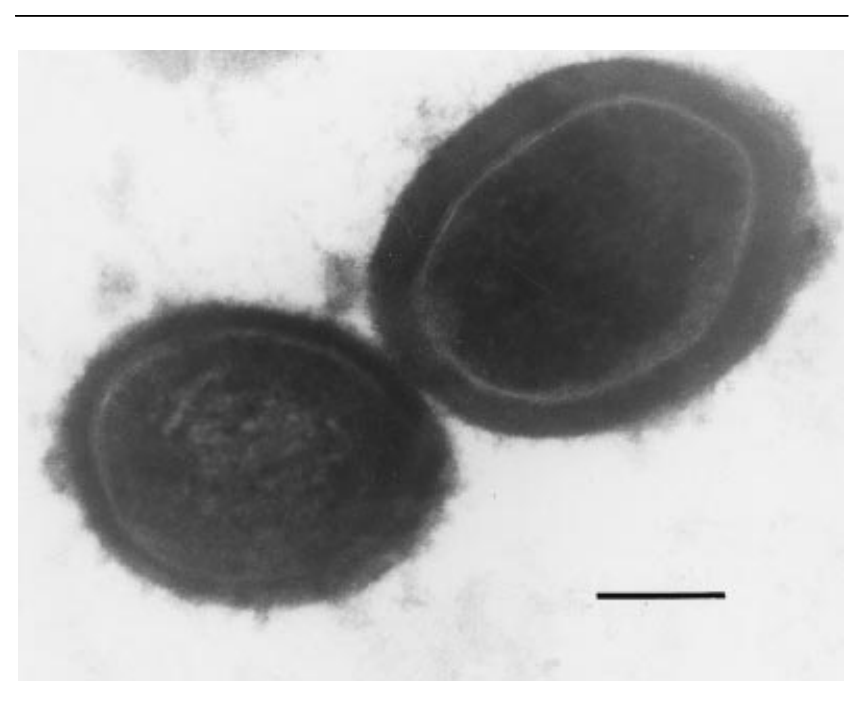

Fig. 1. Transmission electron micrograph of Bulleidia extructa DSM $13220^{\top}$. Ultrathin section showing the Gram-positive cell wall and the cytoplasmic membrane. Bar, $0.2 \mu \mathrm{m}$ 


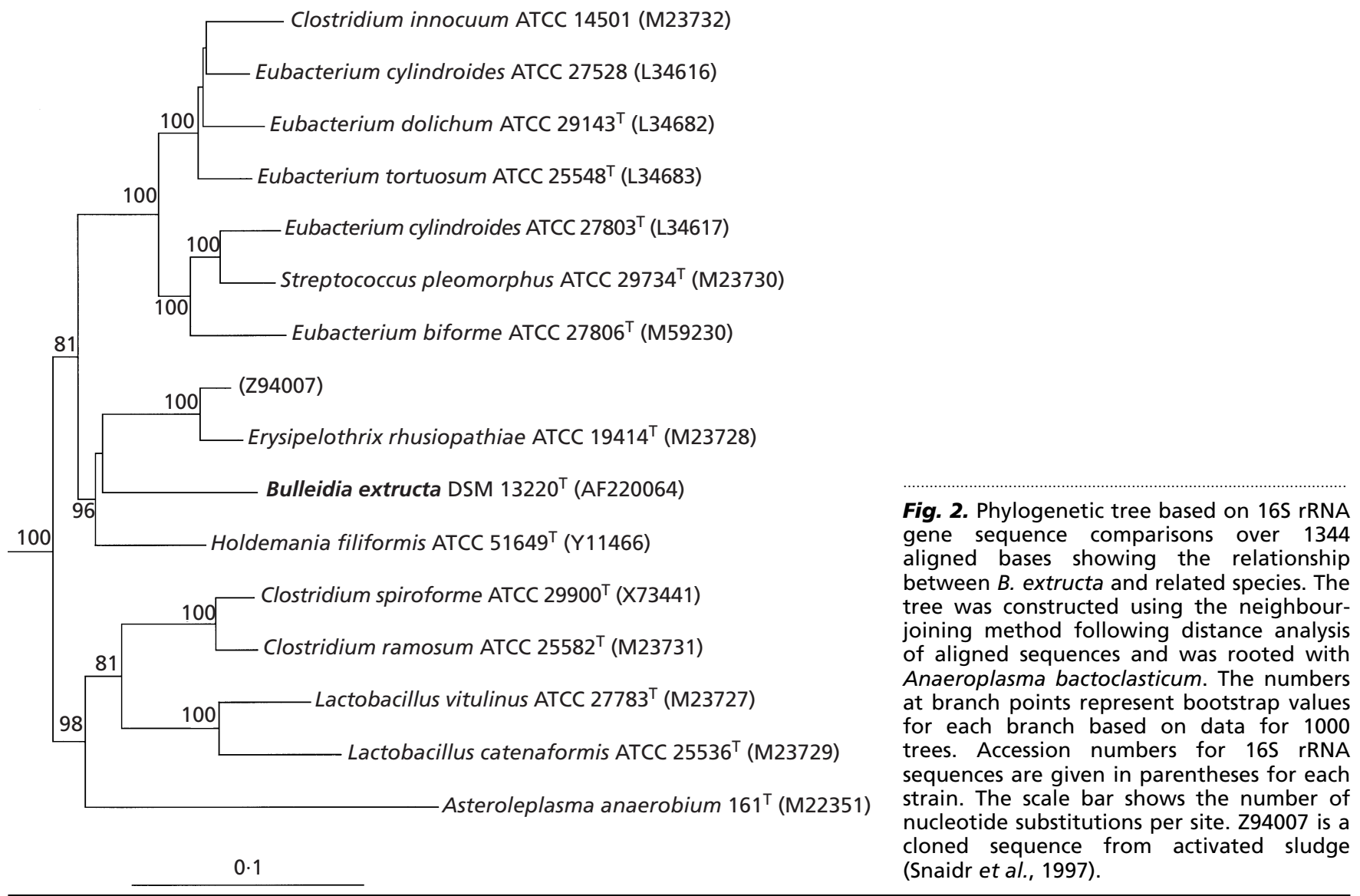

Table 1. Biochemical characteristics of Bulleidia extructa and related species

w, weak.

\begin{tabular}{|lccc|}
\hline & $\begin{array}{c}\text { Bulleidia } \\
\text { extructa }\end{array}$ & $\begin{array}{c}\text { Holdemania } \\
\text { filiformis }\end{array}$ & $\begin{array}{c}\text { Erysipelothrix } \\
\text { rhusiopathiae }\end{array}$ \\
\hline Rapid ID32A profile & 2000012000 & 0500004120 & $2103417^{3} /{ }_{7} 05$ \\
Growth in air + $\mathrm{CO}_{2}$ & - & - & + \\
$\mathrm{H}_{2}$ S production & - & $\mathrm{w}$ & + \\
Aesculin hydrolysis & - & + & - \\
Arginine hydrolysis & + & - & + \\
Growth in 20\% bile & - & $\mathrm{W}$ & + \\
Vancomycin susceptibility (5 $\mu \mathrm{g}$ disc) & $\mathrm{S}$ & 38 & $\mathrm{R}$ \\
DNA G+C content (mol \%) & 38 & Faecal, human & Animal faecal, \\
Habitat & Oral, human & & environmental, \\
& & & human infection \\
\hline
\end{tabular}

teria division (Fig. 2). Nearest relatives were Erysipelothrix rhusiopathiae and the recently described Holdemania filiformis (Willems et al., 1997). 16S rDNA sequence similarities between the strains sequenced in this study and both E. rhusiopathiae and H. filiformis were below $90 \%$, and therefore the new strains were sufficiently distinct to warrant proposal of a new genus and species.
Members of the proposed taxon, for which the name Bulleidia extructa is proposed below, were obligate anaerobes and sensitive to metronidazole, unlike $E$. rhusiopathiae. Strains were also sensitive to $20 \%$ bile, unlike both E. rhusiopathiae and H. filiformis. Biochemical characteristics which enable the new species to be distinguished from $H$. filiformis and E. rhusiopathiae are given in Table 1 . In addition, B. extructa 


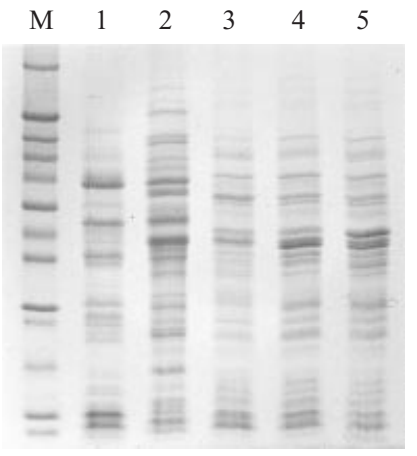

Fig. 3. Protein profiles of $B$. extructa, E. rhusiopathiae and $H$. filiformis. Lanes: 1, E. rhusiopathiae NCTC $8163^{\top} ; 2, H$. filiformis ATCC $51649^{\top} ; 3$, B. extructa DSM $13220^{\top}\left(=\mathrm{W} 1219^{\top}\right) ; 4, B$. extructa UM3; 5 , $B$. extructa GF10; M, molecular mass markers $(6 \cdot 5,14 \cdot 2,20 \cdot 1,24,29,36,45,55,66,84,97 \cdot 4,116$ and $205 \mathrm{kDa})$.

can be distinguished from $E$. rhusiopathiae and $H$. filiformis by comparison of their protein profiles (Fig. 3).

\section{Description of Bulleidia gen. nov.}

Bulleidia (Bull.eid'ia. M.L. n. Bulledia named to honour Arthur Bulleid, distinguished British oral microbiologist).

Cells are obligately anaerobic, non-spore-forming, non-motile, Gram-positive short bacilli. Principal end products of glucose fermentation are acetate and lactate, with trace amounts of succinate produced. Growth in broth media is poor but is stimulated by $0.5 \%$ Tween 80 in the presence of fermentable carbohydrates. Arginine is hydrolysed and there is no growth in $20 \%$ bile. Catalase and indole are not produced and nitrate is not reduced. The type species is Bulleidia extructa.

\section{Description of Bulleidia extructa sp. nov.}

Bulleidia extructa (ex.truc'ta. L. adj. extructus slow, referring to the slow growth of the organism).

Description is based on four strains isolated from the oral cavity. Cells are obligately anaerobic, non-sporeforming, non-motile, Gram-positive short bacilli $(0.5 \times 0.8-2 \mu \mathrm{m})$ occurring singly and in pairs, aligned side by side. After $7 \mathrm{~d}$ incubation on FAA plates, colonies are $0.8 \mathrm{~mm}$ in diameter, circular, entire, low convex, grey to off-white, opaque and glossy. Growth in PRAS media $+0.5 \%$ Tween 80 is poor with arabinose, cellobiose, lactose, mannitol, mannose, melezitose, melibiose, raffinose, rhamnose, salicin, sorbitol, sucrose, trehalose or xylose. Growth is stimulated by fructose, glucose and maltose in the presence of $0.5 \%$ Tween 80. Glucose and maltose are fermented; fructose is not fermented. Moderate amounts of acetate and lactate and trace amounts of succinate are produced as the end products of glucose metabolism in PYG. Arginine is hydrolysed. Catalase and indole are not produced; nitrate is not reduced. Aesculin and urea are not hydrolysed. There is no growth in $20 \%$ bile. Gelatin is not liquefied and $\mathrm{H}_{2} \mathrm{~S}$ is not produced. The $\mathrm{G}+\mathrm{C}$ content of the DNA of the type strain is $38 \mathrm{~mol} \%$. The type strain is DSM $13220^{\mathrm{T}}\left(\mathrm{W} 1219^{\mathrm{T}}\right)$. Isolated from human periodontal pockets and dentoalveolar infections.

\section{ACKNOWLEDGEMENTS}

Ms A. Boyd is thanked for performing the electron microscopy and $\operatorname{Dr} \mathrm{M}$. Munson for additional DNA sequencing.

\section{REFERENCES}

Cheeseman, S. L., Hiom, S. J., Weightman, A. J. \& Wade, W. G. (1996). Phylogeny of oral asaccharolytic Eubacterium species determined by 16S rDNA sequence comparison and proposal of Eubacterium infirmum sp. nov. and Eubacterium tardum sp. nov. Int J Syst Bacteriol 46, 957-959.

Felsenstein, J. (1993). PHYLIP (Phylogeny Inference Package) version 3.5c. Seattle, WA: Department of Genetics, University of Washington.

Holdeman, L. V. H., Cato, E. P. \& Moore, W. E. C. (1977). Anaerobe Laboratory Manual, 4th edn. Blacksburg, VA: Virginia Polytechnic Institute and State University.

Lane, D. J. (1991). 16S/23S rRNA sequencing. In Nucleic Acid Techniques in Bacterial Systematics, pp. 115-175. Edited by E. Stackebrandt \& M. Goodfellow. Chichester: Wiley.

Moore, W. E. C. \& Holdeman Moore, L. V. H. (1986). Genus Eubacterium Prévot 1938. In Bergey's Manual of Systematic Bacteriology, vol. 2, pp. 1353-1373. Edited by P. H. A. Sneath, N. S. Mair, M. E. Sharpe \& J. G. Holt. Baltimore: Williams \& Wilkins.

Neefs, J.-M., Van de Peer, Y., De Rijk, P., Chapelle, S. \& De Wachter, R. (1993). Compilation of small ribosomal subunit RNA structures. Nucleic Acids Res 21, 3025-3049.

Olsvik, B. (1995). Tetracycline resistance in oral bacteria - a study of bacterial isolates from patients with refractory periodontal diseases. PhD thesis. University of Oslo.

Poco, S. E., Jr, Nakazawa, F., Sato, M. \& Hoshino, E. (1996a). Eubacterium minutum sp. nov., isolated from human periodontal pockets. Int J Syst Bacteriol 46, 31-34.

Poco, S. E., Jr, Nakazawa, F., Ikeda, T., Sato, M., Sato, T. \& Hoshino, E. (1996b). Eubacterium exiguum sp. nov., isolated from human oral lesions. Int J Syst Bacteriol 46, 1120-1124.

Slayne, M. A., Aldred, M. J. \& Wade, W. G. (1990). A rapid, semiautomated SDS-PAGE identification system for oral anaerobic bacteria. J Appl Bacteriol 68, 391-395.

Snaidr, J., Amann, R., Huber, I., Ludwig, W. \& Schleifer, K.-H. (1997). Phylogenetic analysis and in situ identication of bacteria in activated sludge. Appl Environ Microbiol 63, 2884-2896.

Summanen, P., Baron, E. J., Citron, D. M., Strong, C. A., Wexler, H. M. \& Finegold, S. M. (1993). Wadsworth Anaerobic Bacteriology Manual, 5th edn. Belmont, CA: Star Publishing.

Thompson, J. D., Higgins, D. G. \& Gibson, T. J. (1994). CLUSTAL $\mathrm{W}$ : improving the sensitivity of progressive multiple sequence alignment through sequence weighting, position-specific gap penalties and weight matrix choice. Nucleic Acid Res 22, 4673-4680.

Uematsu, H., Nakazawa, F., Ikeda, T. \& Hoshino, E. (1993). 
Eubacterium saphenum sp. nov., isolated from human periodontal pockets. Int J Syst Bacteriol 43, 302-304.

Wade, W. G. (1997). The role of Eubacterium species in periodontal disease and other oral infections. Microb Ecol Health Dis 9, 367-370.

Wade, W. G., Slayne, M. A. \& Aldred, M. J. (1990). Comparison of identification methods for asaccharolytic Eubacterium species. J Med Microbiol 33, 239-242.

Wade, W. G., Downes, J., Dymock, D., Hiom, S. J., Weightman, A. J., Dewhirst, F. E., Paster, B. J., Tzellas, N. \& Coleman, B. (1999).
The family Coriobacteriaceae: reclassification of Eubacterium exiguum (Poco et al., 1996) and Peptostreptococcus heliotrinreducens (Lanigan 1976) as Slackia exigua gen. nov., comb. nov., and Slackia heliotrinireducens gen. nov., comb. nov. and Eubacterium lentum Prevot 1938 as Eggerthella lenta gen. nov., comb. nov. Int J Syst Bacteriol 49, 595-600.

Willems, A., Moore, W. E. C., Weiss, N. \& Collins, M. D. (1997). Phenotypic and phylogenetic characterization of some Eubacterium-like isolates containing a novel type B wall murein from human feces: description of Holdemania filiformis gen. nov., sp. nov. Int J Syst Bacteriol 47, 1201-1204. 